\title{
Tinjauan Ekonomis Penggunaan Sistem Airbag Dan Sistem Cradle Pada Proses Pengedokan Kapal \\ Di PT. Dok Dan Per Kapalan Waiame (Persero) Ambon
}

\author{
P. S. Rumodar ${ }^{1}$, M. F. Noya ${ }^{2}$, N. L. T. Thenu ${ }^{3}$ dan G. S. Norimarna ${ }^{4}$ \\ 1Program Studi Tekni Sistem Perkapalan Fakultas Teknik Universitas Pattimura, Ambon 97233 \\ 1psrumodar@gmail.com \\ 2Program Studi Teknik Sistem Perkapalan Universitas Pattimura \\ Email : mesak.frits.noya@fatek.unpatti.ac.id \\ 3 Program Studi Teknik Sistem Perkapalan Universitas Pattimura \\ Email : novitha.thenu@fatek.unpatti.ac.id \\ 4 Program Studi Teknik Sistem Perkapalan Universitas Pattimura \\ Emai : gsnorimarna@fatek.unpatti.ac.id
}

\begin{abstract}
Abstrak PT. Dok dan perkapalan Waiame Ambon adalah perusahaan reparasi kapal yang memiliki dua fasilitas pengedokan dengan menggunakan sistem airbag dan cradle. Pengamatan di galangan, sistem airbag dilengkapi dengan winch, kompresor dan alat berat (excavator) pada proses docking/undocking kapal sedangkan dengan sistem cradle dilengkapi dengan winch dan operator penyelam pada proses docking kapal. Proses dan waktu docking/undocking baik dengan sistem airbag dan sistem cradle akan berbeda, dengan kondisi ini maka biaya operasional (docking/undocking kapal) perlu diperhitungkan. Biaya operasional docking/undocking kapal dengan sistem airbag sebesar $\mathrm{Rp} 25.000 .000$,- dan sistem cradle sebesar Rp 20.000.000,-. Perbedaan biaya operasional dari masing-masing sistem pengedokan ini dapat mempengaruhi biaya operasional docking/undocking kapal pada perusahaan. Tujuan penelitian ini adalah memperoleh nilai ekonomis yang didapat oleh perusahaan dengan menggunakan sistem airbag dan sistem cradle. Penelitian ini melakukan perhitungan meliputi biaya listrik winch, biaya listrik kompresor, biaya operasi alat berat (excavator), biaya operasional (docking/undocking kapal), biaya docking harian dan kebutuhan tenaga kerja. Dari hasil perhitungan diperoleh bahwa biaya pengeluaran untuk sistem airbag dari tahun 2017-2019 sebesar Rp 760.483.125 dan sistem cradle sebesar Rp. $519,091,188$, sedangkan pendapatan yang didapat dari sistem airbag sebesar Rp. 3,593,750,000 dan sistem cradle sebesar Rp. 1.728.750.000. Dari hasil di atas pendapatan terbanyak adalah pendapatan sistem airbag di tahun 2019 yaitu $79 \%$. Hal ini disebabkan karena lama waktu pengedokan pada sistem airbag lebih banyak walaupun jumlah kapal hanya 14. Keuntungan yang diperoleh dengan penggunaan sistem airbag per tiga tahun yaitu tahun 2017-2019 adalah sebesar Rp. 2.833.266.875,- , lebih besar jika dibandingkan dengan keuntungan yang didapat dengan menggunakan sistem cradle sebesar Rp. 1.209.658.812,50. Terlihat jelas bahwa penggunaan sistem airbag lebih menguntungkan.
\end{abstract}

Kata kunci: airbag, cradle, docking, undocking, laba bersih

\begin{abstract}
PT. Dock and Shipping Waiame Ambon is a ship repair company that has two docking facilities using an airbag and cradle system. Observations at the shipyard, the airbag system is equipped with a winch, compressor, and heavy equipment (excavator) in the ship docking/undocking process, while the cradle system is equipped with winch and diver operators in the ship docking process. The process and time of docking/undocking both with the airbag system and the cradle system will be different, with this condition operational costs (docking/undocking ships) need to be taken into account. The operational cost of docking/undocking ships with an airbag system is Rp. 25,000,000, - and the cradle system is $R p .20,000,000$. The difference in operational costs of each of these docking systems can affect the company's ship docking/undocking operational costs. The purpose of this study is to obtain the economic value obtained by the company by using the airbag system and cradle
\end{abstract}


system. This study performs calculations that include winch electricity costs, compressor electricity costs, heavy equipment (excavator) operating costs, operational costs (shipbuilding/docking), daily docking costs and labor requirements. From the calculation results, the expenditure for the airbag system from 2017-2019 was Rp.760.483.125 and the cradle system was $R p$. 519,091,188, while the revenue from the airbag system is $R p$. $3,593,750,000$ and the cradle system is $R p .1,728,750,000$. From the results above, the largest revenue was airbag system revenue in 2019, which was $79 \%$. This is because the docking time on the airbag system is more even though the number of ships is only 14. The profit obtained by using the airbag system per three years, namely 2017-2019 is Rp. 2,833,266,875, - greater than the profit obtained by using the cradle system of $R p .1,209,658,812.50$. The use of an airbag system is more profitable.

Keywords: airbag, cradle, docking, undocking, net profit

\section{PENDAHULUAN}

PT. Dok dan Perkapalan Waiame (Persero) Ambon adalah perusahaan reparasi kapal yang mempunyai dua fasilitas pengedokan kapal dengan menggunakan sistem airbag dan sistem cradle. Teknologi menaikkan dan menurunkan kapal menggunakan fasilitas sistem airbag sudah banyak dipergunakan oleh galangan kapal di Indonesia, namun tidak sedikit juga galangan yang masih menggunakan fasilitas sistem cradle untuk menaikkan dan menurunkan kapal.

Penggunaan kedua fasilitas pengedokan ini berhubungan dengan biaya operasional docking/undocking kapal dengan sistem airbag sebesar Rp 25.000.000,- dan sistem cradle sebesar Rp 20.000.000,-. Perbedaan biaya operasional dari masing-masing sistem pengedokan ini dapat mempengaruhibiaya operasional docking/undocking kapal di perusahaan. Perbedaan biaya operasional ini juga mengarah kepada bagaimana memilih metode untuk investasi yang optimum pada suatu perusahaan perkapalan (Engstrom, Crispe). Jenis docking sistem airbag membutuhkan landasan dan airbag sedang jenis docking dengan sistem cradle menggunakan landasan dan rel (Cornick, Leong, Karogal, Lamb dan Mackie).

Berdasarkan pengamatan di galangan metode sistem airbag dilengkapi dengan winch, compressor dan alat berat (excavator) pada proses docking/undocking kapal sedangkan dengan metode sistem cradle dilengkapi dengan winch dan operator penyelam pada proses docking kapal. Proses dan waktu docking/undocking baik dengan metode sistem airbag dan sistem cradle akan berbeda, dengan kondisi ini maka biaya operasional (docking/ undocking kapal) perlu diperhitungkan juga. Dari penjelasan ini maka diperlukan tinjauan ekonomis biaya operasional sistem airbag dan sistem cradle. Oleh karena itu penelitian ini akan mengulas tentang biaya operasional fasilitas pengedokan menggunakan sistem airbag dan sistem cradle pada PT. Dok dan Perkapalan Waiame (Persero) Ambon. Perhitungan ini meliputi biaya listrik winch, biaya listrik compressor, biaya operasi alat berat (excavator), biaya operasional (docking/undocking kapal), biaya docking harian dan kebutuhan tenaga kerja dari kedua metode tersebut.

\section{BAHAN DAN METODE}

\subsection{Biaya Pengedokan Untuk Docking/Undocking Kapal Selama Periode Tahun 2017, 2018 dan 2019 Pada PT. Dok dan Perkapalan Waiame Ambon.}

Sebelum perhitungan dilakukan diperlukan data docking kapal yang diambil dalam periode tahun 2017-2019 sebagai acuan untuk perhitungan, data yang diambil adalah terdiri dari :

- Data docking kapal pada PT. Dok dan Perkapalan Waiame Ambon Periode tahun 2017, 2018 dan 2019 untuk sistem airbag dan sistem cradle

- Waktu pengedokan kapal

- Jumlah pengedokan dengan sistem airbag dan sistem cradle

- Lama waktu pengedokan

Untuk mengetahui perbandingan biaya operasional dan pendapatan antara sistem airbag dan sistem cradle maka diperlukan perhitungan sebagai berikut :

\section{Biaya docking kapal}

Biaya docking kapal terdiri dari :

a. Biaya tidak tetap

Biaya yang berubah secara proposional dengan aktivitas bisnis. Biaya tidak tetap adalah jumlah 
biaya marjinal terhadap semua unit yang diproduksi, biaya tidak tetap berkaitan dengan volume (dan dibayar per barang atau jasa yang diproduksi)

b. Biaya Tetap

Pengeluaran bisnis yang tidak tergantung pada tingkat barang atau jasa yang dihasilkan oleh bisnis tersebut. Pengeluaran ini berkaitan dengan waktu seperti gaji, atau beban usaha yang harus dibayar setiap bulan dan sering disebut sebagai pengeluaran tambahan.

\section{Pendapatan docking kapal terdiri dari :}

a. Pendapatan docking (docking/undocking)

b. Pendapatan docking harian

\subsection{Biaya Docking/Undocking Kapal untuk Sistem airbag}

\section{Biaya Tidak Tetap untuk Sistem airbag}

a. Perhitungan jumlah Sistem Airbag

Untuk kapal-kapal konvensional, jumlah sistem airbag dihitung dengan menggunakan persamaan sebagai berikut (ISO, 2013) :

$$
\mathrm{N}=\mathrm{K}_{1} \frac{\mathrm{Q} \cdot \mathrm{g}}{\mathrm{C}_{\mathrm{B}} \cdot \mathrm{R} \cdot \mathrm{L}_{\mathrm{d}}}
$$

dimana :

$\mathrm{N}=$ Jumlah Sistem airbag (pcs)

$\mathrm{K}_{1}=$ Nilai konstanta 1,2 -1,3

$\mathrm{Q}=$ Berat kapal yang akan dinaikkan (ton)

$\mathrm{g}=$ Percepatan gravitasi $;\left(\mathrm{m} / \mathrm{s}^{2}\right)$

$\mathrm{CB}=$ Koefesien blok kapal

$\mathrm{R}=$ Garansi kekuaatan bantalan Sistem airbag per satuan meter panjang dari Sistem airbag ; KN/m (nilai dapat dilihat pada Tabel 2.1)

$\mathrm{Ld}=$ Panjang kontak antara Sistem airbag dengan alas lambung kapal pada parallel uniddle body $(\mathrm{m})$ seperti ditunjukkan pada Gambar 1.

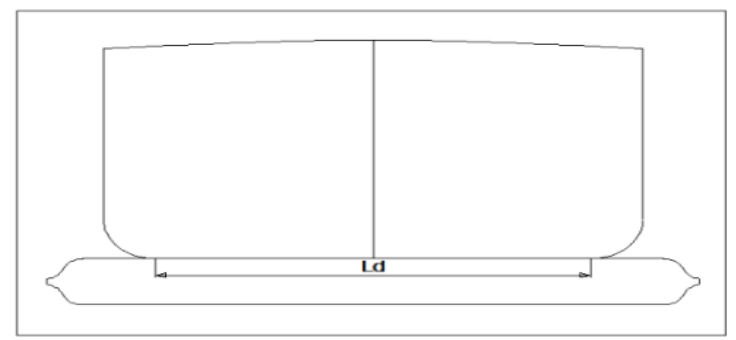

Gambar 1. Jarak antara sistem airbag dan alas kapal (Ld) (Sitepu,2012): Panjang kontak
Jarak sumbu antara sistem airbag diperhitungkan untuk mendapatkan kekuatan memanjang kapal dan untuk menghindari overlapping dari putaran sistem airbag. Berikut ini adalah tabel klasifikasi berdasarkan diameter sistem airbag seperti ditunjukkan pada (Tabel 2.1).

Tabel 1. Klasifikasi berdasarkan diameter Sistem airbag (ISO 2013).

\begin{tabular}{|c|c|c|c|c|c|}
\hline \multirow{2}{*}{ Diameter } & \multirow{2}{*}{$\begin{array}{c}\text { Kerja } \\
\text { pressure }\end{array}$} & \multirow{2}{*}{ Tinggi kerja } & \multicolumn{3}{|c|}{ Dijamin daya dukung persatuan panjang } \\
\hline & & & $\mathrm{Kn} / \mathbf{m}$ & $\mathbf{T} / \mathbf{m}$ & Lb/ft \\
\hline \multirow{6}{*}{$\begin{array}{c}\mathrm{D}=1,2 \mathrm{~m} \\
(\mathrm{D}=1,394 \mathrm{ft})\end{array}$} & \multirow{6}{*}{$\begin{array}{l}\text { 0,17Mpa } \\
(24,66 \mathrm{ft})\end{array}$} & $0,7 \mathrm{~m}(2.296 \mathrm{ft})$ & 133,61 & 13,62 & 9154 \\
\hline & & $0,6 \mathrm{~m}(1,968 \mathrm{ft})$ & 160,30 & 16,34 & 10983 \\
\hline & & $0,5 \mathrm{~m}(1,640 \mathrm{ft})$ & 187,08 & 19,07 & 12818 \\
\hline & & $0,4 \mathrm{~m}(1,312 \mathrm{ft})$ & 213,76 & 21,79 & 14646 \\
\hline & & $0,3 \mathrm{~m}(0,984 \mathrm{ft})$ & 240,44 & 24,51 & 16474 \\
\hline & & $0,2 \mathrm{~m}(0,656 \mathrm{ft})$ & 267,22 & 27,24 & 18309 \\
\hline \multirow{8}{*}{$\begin{array}{c}\mathrm{D}=1,5 \mathrm{~m} \\
(\mathrm{D}=4,92 \mathrm{ft})\end{array}$} & \multirow{8}{*}{$\begin{array}{c}0,13 \mathrm{Mpa} \\
(18,85 \mathrm{psi})\end{array}$} & $0,9 \mathrm{~m}(2,952 \mathrm{ft})$ & 122,63 & 12,50 & 8402 \\
\hline & & $0,8 \mathrm{~m}(2,624 \mathrm{ft})$ & 143,03 & 14,58 & 9800 \\
\hline & & $0,7 \mathrm{~m}(2,296 \mathrm{ft})$ & 163,43 & 16,66 & 11198 \\
\hline & & $0,6 \mathrm{~m}(1,968 \mathrm{ft})$ & 183,94 & 18,75 & 12602 \\
\hline & & $0,5 \mathrm{~m}(1,640 \mathrm{ft})$ & 204,34 & 20,83 & 14000 \\
\hline & & $0,4 \mathrm{~m}(1,312 \mathrm{ft})$ & 224,75 & 22,91 & 15398 \\
\hline & & $0,3 \mathrm{~m}(0,984 \mathrm{ft})$ & 245,15 & 24,99 & 16797 \\
\hline & & $0,2 \mathrm{~m}(0,656 \mathrm{ft})$ & 267,81 & 27,30 & 18349 \\
\hline \multirow{10}{*}{$\begin{array}{c}\mathrm{D}=1,8 \mathrm{~m} \\
(\mathrm{D}=5,90 \mathrm{ft})\end{array}$} & \multirow{10}{*}{$\begin{array}{c}0,11 \mathrm{Mpa} \\
\text { (15,95Psi) }\end{array}$} & $1,1 \mathrm{~m}(3,608 \mathrm{ft})$ & 120,96 & 12,33 & 8287 \\
\hline & & $1,0 \mathrm{~m}(3,280 \mathrm{ft})$ & 138,22 & 14,09 & 9470 \\
\hline & & $0,9 \mathrm{~m}(2,952 \mathrm{ft})$ & 155,59 & 15,86 & 10660 \\
\hline & & $0,8 \mathrm{~m}(2,624 \mathrm{ft})$ & 172,85 & 17,62 & 11843 \\
\hline & & $0,7 \mathrm{~m}(2,296 \mathrm{ft})$ & 190,22 & 19,39 & 13033 \\
\hline & & $0,6 \mathrm{~m}(1,968 \mathrm{ft})$ & 207,48 & 21,15 & 14216 \\
\hline & & $0,5 \mathrm{~m}(1,640 \mathrm{ft})$ & 224,75 & 22,91 & 15398 \\
\hline & & $0,4 \mathrm{~m}(1,312 \mathrm{ft})$ & 242,01 & 24,67 & 16581 \\
\hline & & $0,3 \mathrm{~m}(0,984 \mathrm{ft})$ & 259,38 & 26,44 & 17771 \\
\hline & & $0,2 \mathrm{~m}(0,656 \mathrm{ft})$ & 276,64 & 28,20 & 18954 \\
\hline
\end{tabular}

b. Lama waktu operasional untuk docking kapal pada sistem airbag.

Lama waktu operasional docking kapal airbag terdiri dari:

- Waktu pengisian untuk satu airbag

- Lama waktu tarik

- Lama waktu turun.

c. Perhitungan biaya listrik untuk docking kapal pada sistem airbag

Biaya operasional listrik untuk docking satu kapal dengan sistem airbag, meliputi :

i. Biaya listrik winch sistem airbag, B Winch

$\mathrm{B}_{\text {Winch }}=$ T.W. c

dimana :

$\mathrm{T}=$ Lama waktu tarik (docking/undocking)

$\mathrm{w}=$ Daya listrik Winch

$\mathrm{c}=$ Tarif listrik per kwh 
ii. Biaya listrik untuk operasional kompresor

Biaya listrik untuk satu sistem airbag, B (sistem airbag)

$$
\mathrm{B}=\mathrm{T} \cdot \mathrm{w} \cdot \mathrm{c}
$$

Jumlah biaya listrik, Bn

$\mathrm{Bn}=\mathrm{B} \cdot \mathrm{N}$

dimana :

$$
\begin{aligned}
\mathrm{T} & =\text { Waktu pengisian sistem airbag } \\
\mathrm{w} & =\text { Daya compresor } \\
\mathrm{c} & =\text { Tarif listrik per kwh } \\
\mathrm{N} & =\text { Jumlah sistem airbag }
\end{aligned}
$$

d. Perhitungan biaya operasional alat berat

Perhitungan biaya operasi alat berat (excavator) digunakan persamaan berikut:

Biaya Alat Berat $=$ jumlah unit Alat Berat $\times$ Biaya operasi

e. Asisten operator airbag

Perhitungan asisten operator airbag menggunakan persamaan berikut:

Upah asisten airbag $=$ Upah per kapal $\times$ jumlah tenaga kerja $\times$ jumlah kapal

\section{Biaya Tetap Pada Proses Docking/Undocking Kapal Untuk Sistem Airbag}

Perhitungan upah tenaga kerja yang dihitung per bulan sebagai berikut:

a. Upah tenaga kerja untuk operasional sistem airbag per bulan terdiri dari (Heger, 2005) :

Upah dok master $=$

Upah per bulan x jumlah tenaga kerja

Upah operator winch $=$

Upah per bulan $\mathrm{x}$ jumlah tenaga kerja

Upah operator airbag $=$

Upah per bulan $\mathrm{x}$ jumlah tenaga kerja

b. Upah tenaga kerja untuk operasional sistem airbag per pahun.

Perhitungan biaya tetap untuk sistem airbag per tahun terdiri dari :

a. Upah dok master

b. Upah operator winch c. Upah operator sistem airbag

d. Asisten operator winch

\subsection{Pendapatan Docking/Undocking dan Harian Untuk Sistem Airbag}

1. Pendapatan Per Tahun dari Docking/ Undocking Kapal

Perhitungan pendapatan docking/undocking kapal per tahun menggunakan persamaan berikut :

Pendapatan per tahun = biaya docking / undocking $\times$ jumlah kapal

\section{Pendapatan Per Tahun dari Biaya Docking Harian}

Perhitungan pendapatan docking harian per tahun menggunakan persamaan berikut:

Pendapatan per tahun $=$

Biaya docking per hari $x$

Lama waktu docking

\subsection{Perhitungan Laba Rugi Sistem Airbag Tahun 2017-2019}

Perhitungan laba rugi bersih untuk biaya operasioanal rata-rata sistem airbag. Untuk perhitungan laba rugi bersih pada biaya operasional dapat digunakan persamaan berikut (Fitriana, 2014):

- Pendapatan kotor rata-rata, $N_{P}$

$$
N P=\frac{A+B+C}{3}
$$

- Jumlah beban usaha rata-rata, $N_{B}$

$$
N B=\frac{A+B+C}{3}
$$

- Laba rugi/bersih rata-rata, $N_{L}$

$$
N L=N P-N B
$$

dimana:

$\mathrm{N}=$ Jumlah laba rugi bersih rata-rata
$\mathrm{A}=$ Pendapatan kotor/Jumlah beban usaha/laba bersih tahun pertama 2017
$\mathrm{B}=$ Pendapatan kotor/Jumlah beban usaha/laba bersih tahun kedua 2018
$\mathrm{C}$ = Pendapatan kotor/Jumlah beban usaha/laba bersih tahun ketiga 2019 


\subsection{Biaya Docking/Undocking Kapal Untuk Sistem Cradle}

\section{Biaya Tidak Tetap Untuk Sistem Cradle}

a. Lama waktu operasional untuk docking kapal pada sistem cradle.

Lama waktu operasional docking kapal sistem cradle terdiri dari:

- Lama waktu tarik

- Lama waktu turun.

b. Perhitungan biaya listrik untuk docking kapal pada sistem cradle.

Biaya operasional listrik untuk docking satu kapal dengan sistem cradle meliputi :

Biaya listrik winch sistem cradle, B Winch

$B$ winch $=T \cdot w \cdot c$

dimana :

$\mathrm{T}=$ Lama waktu tarik (docking/undocking

$\mathrm{w}=$ Daya listrik Winch

$\mathrm{c}=$ Tarif listrik per $\mathrm{kwh}$

c. Perhitungan upah penyelam

Upah penyelam = Upah per kapal $\times$

jumlah tenaga kerja $\times$ jumlah kapal...(16)

d. Asisten operator cradle

Upah asisten cradle Upah per kapal $\times$ jumlah tenaga kerja $\times$ jumlah kapal

Dari besar upah yang ditetapkan untuk upah penyelam, operator alat berat, asisten operator cradle dan asisten operator airbag per kapal maka dapat dihitung upah per tahun.

\section{Biaya Tetap Pada Proses Docking Kapal Untuk Sistem Cradle}

Perhitungan upah tenaga kerja yang dihitung per bulan sebagai berikut:

a. Upah tenaga kerja untuk operasional sistem cradle per bulan terdiri dari:

Upah dok master $=$ Upah per bulan $\times$ jumlah tenaga kerja

Upah operator winch $=$ Upah per bulan $\times$ jumlah tenaga kerja

Upah operator sistem cradle $=$ Upah per bulan $\times$ jumlah tenaga kerja b. Upah tenaga kerja untuk operasional sistem cradle per tahun

Perhitungan biaya tetap untuk sistem cradle per tahun terdiri dari :

- Upah dok master

- Upah operator winch

- Upah operator sistem cradle

- Asisten operator winch

\subsection{Perhitungan Pendapatan Docking Kapal} Untuk Sistem Cradle

1. Pendapatan Per Tahun dari Docking /Undocking Kapal

Perhitungan pendapatan docking/undocking kapal per tahun digunakan persamaan berikut (Mallick, :

Pendapatan per tahun = biaya docking/ undocking $\times$ jumlah kapal

\section{Pendapatan Per Tahun dari Biaya Docking Harian}

Perhitungan pendapatan docking harian per tahun digunakan persamaan berikut:

Pendapatan per tahun $=$

Biaya docking per hari $\times$ Lama waktu docking

\subsection{Perhitungan Laba Rugi Sistem Cradle Tahun 2017-2019}

Perhitungan laba rugi bersih untuk biaya operasioanal rata-rata sistem cradle. Untuk perhitungan laba rugi bersih pada biaya operasional dapat digunakan persamaan berikut:

- Pendapatan kotor rata-rata, $N_{P}$

$$
N P=\frac{A+B+C}{3}
$$

- Jumlah beban usaha rata-rata, $N_{B}$

$$
N B=\frac{A+B+C}{3}
$$

- Laba rugi/bersih rata-rata, $N_{L}$

$$
N L=N P-N B
$$

dimana:

$\mathrm{N}=$ Jumlah laba rugi bersih rata-rata

$\mathrm{A}=$ Pendapatan kotor/Jumlah beban usaha/laba bersih tahun pertama 2017

$\mathrm{B}=$ Pendapatan kotor/Jumlah beban usaha/laba bersih tahun kedua 2018

$\mathrm{C}=$ Pendapatan kotor/Jumlah beban usaha/laba bersih tahun ketiga 2019 


\section{HASIL DAN PEMBAHASAN}

Besarnya biaya yang dibutuhkan untuk operasional sistem airbag dan sistem cradle, dibutuhkan data docking kapal untuk menghitung biaya operasional sistem airbag dan sistem cradle. Data yang diambil pada penelitian ini adalah tiga tahun dihitung dari Tahun 2017-2019.

\subsection{Biaya Docking/undocking Kapal Dengan Sistem Airbag Sebuah Kapal.}

Biaya dan pendapatan untuk docking kapal dilakukan untuk mengetahui besarnya biaya yang dibutuhkan untuk operasional sistem airbag. Komponen - komponen biaya yang diperhitungkan adalah biaya tidak tetap dan biaya tetap seperti yang ditunjukkan pada Tabel 2 dan 3.

Biaya tidak tetap yang dibutuhkan oleh sebuah kapal dapat dilihat pada Tabel 2 berikut ini:

Tabel 2. Biaya Tidak Tetap untuk Docking/Undocking Sistem Airbag.

\begin{tabular}{|c|c|c|c|}
\hline \multicolumn{2}{|c|}{ Biaya Tidak Tetap } & \multirow{2}{*}{$\begin{array}{l}\text { Satuan } \\
\text { pcs }\end{array}$} & \multirow{2}{*}{$\begin{array}{l}\text { Jumlah } \\
12\end{array}$} \\
\hline a. & $\begin{array}{l}\text { Jumlah airbag sistem per } \\
\text { kapal }\end{array}$ & & \\
\hline b. & $\begin{array}{l}\text { Lama waktu operasional } \\
\text { airbag sistem }\end{array}$ & & \\
\hline i. & $\begin{array}{l}\text { Lama waktu } \\
\text { docking/undocking Kapal }\end{array}$ & jam & 3 \\
\hline ii. & $\begin{array}{l}\text { Lama waktu pengisian } \\
\text { udara }\end{array}$ & $\begin{array}{l}\text { menit/air } \\
\text { bag }\end{array}$ & 10 \\
\hline c. & $\begin{array}{l}\text { Biaya listrik untuk } \\
\text { operasional airbag }\end{array}$ & & \\
\hline i. & $\begin{array}{l}\text { Biaya listrik operasional } \\
\text { winch }\end{array}$ & Per Kapal & $\mathrm{Rp} \quad 250.875$ \\
\hline ii. & $\begin{array}{l}\text { Biaya listrik operasional } \\
\text { compressor }\end{array}$ & Per Kapal & Rp $\quad 167.250$ \\
\hline d. & $\begin{array}{l}\text { Biaya operasional alat } \\
\text { berat }\end{array}$ & Per Kapal & Rp 1.000 .000 \\
\hline e. & Biaya pekerja & & \\
\hline i. & Operator Alat Berat & Per Kapal & Rp $\quad 750.000$ \\
\hline ii. & Asisten Operator Airbag & Per Kapal & $\mathrm{Rp} \quad 1.400 .000$ \\
\hline
\end{tabular}

Biaya tetap yang dibutuhkan oleh sebuah kapal ditunjukkan pada Tabel 3 berikut ini :

Table 3. Biaya Tetap untuk Docking/Undocking Sebuah Kapal.

\begin{tabular}{|c|c|c|c|c|c|}
\hline \multirow[t]{2}{*}{ No } & \multirow{2}{*}{$\begin{array}{c}\text { Jenis } \\
\text { Pekerjaan }\end{array}$} & \multicolumn{2}{|c|}{ Kapasitas } & \multirow{2}{*}{$\begin{array}{l}\text { Upah/ } \\
\text { Bulan } \\
\text { (Rp) }\end{array}$} & \multirow{2}{*}{$\begin{array}{c}\text { Jumlah } \\
\text { Upah / } \\
\text { tahun (Rp) }\end{array}$} \\
\hline & & Jumlah & Satuan & & \\
\hline 1 & Dok Master & 1 & Org & 4.000 .000 & 4.000 .000 \\
\hline
\end{tabular}

\begin{tabular}{|c|l|c|c|c|c|}
\hline 2 & $\begin{array}{l}\text { Operator } \\
\text { winch }\end{array}$ & 1 & Org & 3.000 .000 & 36.000 .000 \\
\hline 3 & $\begin{array}{l}\text { Asisten } \\
\text { Operator } \\
\text { Sistenm } \\
\text { Cradle }\end{array}$ & 2 & Org & 2.800 .000 & 67.200 .000 \\
\hline 4 & $\begin{array}{l}\text { Operator } \\
\text { Airbag }\end{array}$ & 1 & Org & 3.000 .000 & 36.000 .000 \\
\hline & & 5 & Org & & 187.200 .000 \\
\hline
\end{tabular}

\subsection{Biaya Docking/Undocking Kapal Sistem Airbag Tahun 2017}

Biaya docking/undocking kapal Sistem Airbag Tahun 2017 ditunjukkan pada Tabel 4.

Tabel 4. Biaya Docking/Undocking Sistem Airbag Tahun 2017.

\begin{tabular}{|c|c|c|c|c|}
\hline No & Parameter & $\begin{array}{l}\text { Jumlah } \\
\text { Kapal }\end{array}$ & $\begin{array}{c}\text { Biaya / } \\
\text { Satuan } \\
(\mathbf{R p})\end{array}$ & $\begin{array}{c}\text { Biaya Per } \\
\text { tahun (Rp) }\end{array}$ \\
\hline \multicolumn{5}{|c|}{ A. Biaya Tetap } \\
\hline 1 & Dok master & & 4.000 .000 & 48.000 .000 \\
\hline 2 & $\begin{array}{l}\text { Operator } \\
\text { winch }\end{array}$ & & 3.000 .000 & 36.000 .000 \\
\hline 3 & $\begin{array}{l}\text { Asisten } \\
\text { operator } \\
\text { winch }\end{array}$ & & 2.800 .000 & 67.200 .000 \\
\hline 4 & $\begin{array}{l}\text { Operato } \\
\text { airbag }\end{array}$ & & 3.000 .000 & 36.000 .000 \\
\hline \multicolumn{5}{|c|}{ B. Biaya Tidak Tetap } \\
\hline 1 & $\begin{array}{l}\text { Biaya listrik } \\
\text { operasional } \\
\text { winch }\end{array}$ & 23 & 250.875 & 5.770 .125 \\
\hline 2 & $\begin{array}{l}\text { Biaya listrik } \\
\text { operasional } \\
\text { compressor }\end{array}$ & 23 & 167.250 & 3.846 .750 \\
\hline 3 & $\begin{array}{l}\text { Biaya } \\
\text { operasional } \\
\text { alat berat }\end{array}$ & 23 & 1.000 .000 & 23.000 .000 \\
\hline 4 & $\begin{array}{l}\text { Operator } \\
\text { Alat Berat }\end{array}$ & 23 & 750.000 & 17.250 .000 \\
\hline 5 & $\begin{array}{l}\text { Asisten } \\
\text { operator } \\
\text { airbag }\end{array}$ & 23 & 1.400 .000 & 32.200 .000 \\
\hline \multicolumn{4}{|c|}{ Jumlah } & 269.266 .875 \\
\hline
\end{tabular}

\subsection{Biaya Docking/Undocking Kapal Sistem Airbag Tahun 2018}

Biaya docking/undocking kapal sistem airbag tahun 2018 ditunjukkan pada Tabel 5. 
Tabel 5. Biaya Docking/Undocking Sistem Airbag Tahun 2018.

\begin{tabular}{|c|l|c|c|c|}
\hline No & \multicolumn{1}{|c|}{ Parameter } & $\begin{array}{c}\text { Jumlah } \\
\text { Kapal }\end{array}$ & $\begin{array}{c}\text { Biaya / } \\
\text { Satuan (Rp) }\end{array}$ & $\begin{array}{c}\text { Biaya Per } \\
\text { Tahun (Rp) }\end{array}$ \\
\hline \multicolumn{5}{|l|}{ A. Biaya Tetap } \\
\hline 1 & Dok Master & & 4.000 .000 & 48.000 .000 \\
\hline 2 & Operator winch & & 3.000 .000 & 36.000 .000 \\
\hline 3 & $\begin{array}{l}\text { Asisten Operator } \\
\text { Winch }\end{array}$ & & 2.800 .000 & 67.200 .000 \\
\hline 4 & Operator Airbag & & 3.000 .000 & 36.000 .000 \\
\hline B. Biaya Tidak Tetap & $\begin{array}{l}\text { Biaya Listrik } \\
\text { operasional winch }\end{array}$ & 20 & 250.875 & 5.017 .500 \\
\hline 2 & $\begin{array}{l}\text { Biaya Listrik } \\
\text { operasional } \\
\text { kompresor }\end{array}$ & 20 & 167.250 & 3.345 .000 \\
\hline 3 & $\begin{array}{l}\text { Biaya Operasional } \\
\text { alat berat }\end{array}$ & 20 & 1.000 .000 & 20.000 .000 \\
\hline 4 & Operator Alat Berat & 20 & 750.000 & 15.000 .000 \\
\hline 5 & $\begin{array}{l}\text { Asisten Operator } \\
\text { Airbag }\end{array}$ & 20 & 1.400 .000 & 28.000 .000 \\
\hline \multicolumn{4}{|l|}{ Jumlah } & 258.562 .500 \\
\hline
\end{tabular}

\subsection{Biaya Docking/Undocking Kapal Sistem Airbag Tahun 2019}

Biaya docking/undocking kapal sistem airbag Tahun 2019 ditunjukkan pada Tabel 6.

Tabel 6. Biaya Docking/Undocking Sistem Airbag Tahun 2019.

\begin{tabular}{|c|l|c|c|c|}
\hline No & \multicolumn{1}{|c|}{ Parameter } & \multicolumn{1}{|c|}{$\begin{array}{c}\text { Jumlah } \\
\text { Kapal }\end{array}$} & $\begin{array}{c}\text { Biaya / } \\
\text { Satuan } \\
(\mathbf{R p})\end{array}$ & $\begin{array}{c}\text { Biaya Per } \\
\text { Tahun (Rp) }\end{array}$ \\
\hline \multicolumn{2}{|l|}{ A. Biaya Tetap } & & \\
\hline 1 & Dok master & & 4.000 .000 & 48.000 .000 \\
\hline 2 & Operator winch & & 3.000 .000 & 36.000 .000 \\
\hline 3 & $\begin{array}{l}\text { Asisten operator } \\
\text { winch }\end{array}$ & & 2.800 .000 & 67.200 .000 \\
\hline 4 & $\begin{array}{l}\text { Operato airbag } \\
\text { B. Biaya Tidak Tetap }\end{array}$ & 3.000 .000 & 36.000 .000 \\
\hline 1 & $\begin{array}{l}\text { Biaya listrik } \\
\text { operasional } \\
\text { winch }\end{array}$ & 14 & 250.875 & 3.512 .250 \\
\hline 2 & $\begin{array}{l}\text { Biaya listrik } \\
\text { operasional } \\
\text { compressor }\end{array}$ & 14 & 167.250 & 2.341 .500 \\
\hline
\end{tabular}

\begin{tabular}{|c|l|c|c|c|}
\hline 3 & $\begin{array}{l}\text { Biaya } \\
\text { operasional alat } \\
\text { berat }\end{array}$ & 14 & $\begin{array}{c}1.000 .0 \\
00\end{array}$ & 14.000 .000 \\
\hline 4 & $\begin{array}{l}\text { Operator Alat } \\
\text { Berat }\end{array}$ & 14 & 750.000 & 10.500 .000 \\
\hline 5 & $\begin{array}{l}\text { Asisten operator } \\
\text { airbag }\end{array}$ & 14 & $\begin{array}{c}1.400 .0 \\
00\end{array}$ & 19.600 .000 \\
\hline \multicolumn{3}{|c|}{ Jumlah } & 237.153 .750 \\
\hline
\end{tabular}

\subsection{Pendapatan Docking/Undocking dan Harian Dengan Sistem Airbag Periode 2017-2019.}

Pendapatan Docking/Undocking kapal diperoleh dari jumlah biaya yang dikenakan untuk satu kapal sebesar Rp.25.000.000.- dan biaya yang dikenakan untuk docking kapal per hari sebesar Rp. 1.250.000,Pendapatan periode 2017-2019 ditunjukkan pada Tabel 7.

Tabel 7. Pendapatan docking/undocking dan docking pada periode tahun 2017-2019.

\begin{tabular}{|c|c|l|c|}
\hline No & Tahun & \multicolumn{1}{|c|}{ Parameter } & Jumlah (Rp) \\
\hline \multirow{2}{*}{1} & \multirow{2}{*}{2017} & Docking/undocking Kapal & 575.000 .000 \\
\cline { 3 - 4 } & & Docking harian & 1.045 .000 .000 \\
\hline \multirow{2}{*}{2} & \multirow{2}{*}{2018} & Docking/undocking Kapal & 475.000 .000 \\
\cline { 3 - 4 } & & Docking harian & 726.250 .000 \\
\hline \multirow{2}{*}{3} & \multirow{2}{*}{2019} & Docking/undocking Kapal & 350.000 .000 \\
\cline { 3 - 4 } & & Docking harian & $422,500,000$ \\
\hline \multicolumn{2}{|c|}{ Jumlah } & 3.593 .750 .000 \\
\hline
\end{tabular}

\subsection{Perhitungan Laba Rugi Sistem Airbag per Tiga Tahun Dalam Periode 2017-2019}

Tabel 8. Perhitungan Laba Rugi Sistem Airbag Tahun 2017-2019

\begin{tabular}{|l|l|l|}
\hline \multicolumn{3}{|c|}{ Perhitungan Laba Rugi } \\
\hline \multicolumn{2}{|c|}{ Sistem Airbag 2017 - 2019 } \\
\hline Pendapatan & Rp 1.400.000.000 \\
\hline Docking/undocking kapal & Rp 2.193.750.000 \\
\hline Docking harian & & Rp 3.593.750.000 \\
\hline Jumlah Pendaptan & & \\
\hline & & \\
\hline Beban usaha & $\mathrm{Rp} 144.000 .000$ & \\
\hline Dok master & $\mathrm{Rp} 108.000 .000$ & \\
\hline Operator winch & $\mathrm{Rp} 201.600 .000$ & \\
\hline Ass operator winch & $\mathrm{Rp} 108.000 .000$ & \\
\hline Operator airbag & $\mathrm{Rp} 79.800 .000$ & \\
\hline Ass operator airbag & $\mathrm{Rp} 9.533 .250$ & \\
\hline Operator alat berat & $\mathrm{Rp} 38.250 .000$ & \\
\hline Alat berat & $\mathrm{Rp} 57.000 .000$ & \\
\hline Compressor & $\mathrm{Rp}$ & \\
\hline
\end{tabular}




\begin{tabular}{|l|l|l|}
\hline Winch airbag & $\mathrm{Rp} \quad 14.299 .875$ & \\
\hline Jumlah beban usaha & & $\mathrm{Rp} 760.483 .125$ \\
\hline Laba Bersih & & $\mathrm{Rp} 2.833 .266 .875$ \\
\hline
\end{tabular}

Perhitungan laba bersih untuk biaya operasional sistem airbag per tahun dalam periode tahun 20172019 dapat dihitung dengan menentukan pendapatan kotor rata - rata dan jumlah beban usaha selama tiga tahun adalah sebagai berikut :

Pendapatan kotor rata-rata selama tiga tahun, $\mathrm{N}_{\mathrm{P}}$.

$\mathrm{N}_{\mathrm{P}}=\operatorname{Rp} 1.620 .000 .000+\operatorname{Rp} 1.201 .250 .000+$

$772.500 .000=\operatorname{Rp} 1.197 .916 .666,67$

Jumlah beban usaha rata-rata selama tiga tahun, $\mathrm{N}_{\mathrm{B}}$.

$\mathrm{N}_{\mathrm{B}}=\mathrm{Rp} 269.266 .875+\mathrm{Rp} 254.062 .500+\mathrm{Rp}$

$237.153 .750=\operatorname{Rp} \quad 253.494 .375$

Laba bersih rata-rata selama tiga tahun , $\mathrm{N}_{\mathrm{L}}$ :

$$
\mathrm{N}_{\mathrm{L}}=\mathrm{N}_{\mathrm{P}}-\mathrm{N}_{\mathrm{B}}
$$

$\mathrm{N}_{\mathrm{L}}=$ Rp. 1.197.916.666,67 - Rp. 253.494.375

$$
=\operatorname{Rp} \quad 944.422 .291,67
$$

\subsection{Biaya Docking/undocking Kapal Dengan Sistem Cradle Sebuah Kapal.}

Biaya dan pendapatan untuk docking kapal dilakukan untuk mengetahui besarnya biaya yang dibutuhkan untuk operasional sistem airbag. Komponen - komponen biaya yang diperhitungkan adalah biaya tidak tetap dan biaya tetap seperti yang ditunjukkan pada Tabel 9 dan 10.

Tabel 9. Biaya Tidak Tetap Pada Proses

\begin{tabular}{|c|c|c|c|c|}
\hline \multicolumn{2}{|r|}{ Biaya Tidak Tetap } & \multirow[t]{2}{*}{ Satuan } & \multicolumn{2}{|r|}{ Jumlah } \\
\hline a. & $\begin{array}{l}\text { Lama waktu } \\
\text { operasional sistem } \\
\text { cradle }\end{array}$ & & & \\
\hline & $\begin{array}{l}\text { Lama waktu naik dan } \\
\text { turun kapal }\end{array}$ & jam & & 1.5 \\
\hline b. & $\begin{array}{l}\text { Biaya listrik untuk } \\
\text { operasional cradle }\end{array}$ & & & \\
\hline & $\begin{array}{l}\text { Biaya listrik } \\
\text { operasional winch }\end{array}$ & & $\mathrm{Rp}$ & 125.438 \\
\hline e. & Biaya pekerja & & & \\
\hline $\mathrm{i}$ & Penyelam & Per kapal & $\mathrm{Rp}$ & 1.000 .000 \\
\hline ii. & Asisten operator cradle & Per kapal & $\mathrm{Rp}$ & 450.000 \\
\hline
\end{tabular}
Docking/Undocking Kapal Untuk Sistem Cradle.
Tabel 10. Biaya Tetap Pada Proses

\begin{tabular}{|c|c|c|c|c|c|}
\hline \multirow{2}{*}{ No } & \multirow{2}{*}{$\begin{array}{c}\text { Jenis } \\
\text { Pekerjaan }\end{array}$} & \multicolumn{2}{|c|}{ Kapasitas } & \multirow{2}{*}{$\begin{array}{c}\text { Upah/ } \\
\text { Bulan } \\
\text { (Rp) }\end{array}$} & \multirow{2}{*}{$\begin{array}{l}\text { Jumlah Upah } \\
\text { per tahun } \\
\text { (Rp) }\end{array}$} \\
\hline & & Jumlah & Satuan & & \\
\hline 1 & Dok master & 1 & org & 4.000 .000 & 48.000 .000 \\
\hline 2 & $\begin{array}{l}\text { Operator } \\
\text { winch }\end{array}$ & 1 & org & 3.000 .000 & 36.000 .000 \\
\hline 3 & $\begin{array}{l}\text { Asisten } \\
\text { operator } \\
\text { winch }\end{array}$ & 1 & org & 2.800 .000 & 33.600 .000 \\
\hline 4 & $\begin{array}{l}\text { Upah } \\
\text { operator } \\
\text { cradle }\end{array}$ & 1 & org & 3.000 .000 & 36.000 .000 \\
\hline & Jumlah & 4 & & org & 151.200 .000 \\
\hline
\end{tabular}
Docking/Undocking Kapal Untuk Sistem Cradle.

\subsection{Perhitungan biaya docking/undocking kapal periode tahun 2017, 2018, 2019 dengan menggunakan sistem cradle.}

Biaya pengeluaran untuk sistem cradle selama Tahun 2017 - 2019, ditunjukkan pada Tabel $11 ; 12$ dan 13.

Tabel 11. Pengeluaran docking/ undocking sistem

\begin{tabular}{|c|c|c|c|c|}
\hline No & Parameter & $\begin{array}{l}\text { Jumlah } \\
\text { Kapal }\end{array}$ & $\begin{array}{l}\text { Biaya/Satuan } \\
\text { (Rp) }\end{array}$ & $\begin{array}{l}\text { Biaya Per } \\
\text { Tahun (Rp) }\end{array}$ \\
\hline \multicolumn{5}{|c|}{ A. Biaya Tetap } \\
\hline 1 & Dok master & & 4.000 .000 & 48.000 .000 \\
\hline 2 & Operator winch & & 3.000 .000 & 36.000 .000 \\
\hline 3 & $\begin{array}{l}\text { Asisten } \\
\text { operator winch }\end{array}$ & & 2.800 .000 & 33.600 .000 \\
\hline 4 & $\begin{array}{l}\text { Upah operator } \\
\text { cradle }\end{array}$ & & 3.000 .000 & 36.000 .000 \\
\hline \multicolumn{5}{|c|}{ B. Biaya Tidak Tetap } \\
\hline 1 & $\begin{array}{l}\text { Biaya listrik } \\
\text { operasional } \\
\text { winch }\end{array}$ & 16 & 125.438 & 2.007 .000 \\
\hline 2 & Penyelam & 16 & 1.000 .000 & 16.000 .000 \\
\hline 3 & $\begin{array}{l}\text { Asisten } \\
\text { operator cradle }\end{array}$ & 16 & 450.000 & 7.200 .000 \\
\hline \multicolumn{4}{|c|}{ Jumlah } & 18.807 .000 \\
\hline
\end{tabular}
cradle ditahun 2017.

Tabel 12. Pengeluaran docking/ undocking sistem cradle ditahun 2018.

\begin{tabular}{|l|l|c|c|c|}
\hline No & Parameter & $\begin{array}{c}\text { Jumlah } \\
\text { Kapal }\end{array}$ & $\begin{array}{c}\text { Biaya/Satuan } \\
(\text { Rp) }\end{array}$ & $\begin{array}{c}\text { Biaya Per } \\
\text { Tahun (Rp) }\end{array}$ \\
\hline \multicolumn{4}{|l|}{ A. Biaya Tetap } \\
\hline 1 & Dok master & & 4.000 .000 & 48.000 .000 \\
\hline 2 & Operator winch & & 3.000 .000 & 36.000 .000 \\
\hline
\end{tabular}




\begin{tabular}{|c|c|c|c|c|}
\hline 3 & $\begin{array}{l}\text { Asisten } \\
\text { operator winch }\end{array}$ & & 2.800 .000 & 33.600 .000 \\
\hline 4 & $\begin{array}{l}\text { Upah operator } \\
\text { cradle }\end{array}$ & & 3.000 .000 & 36.000 .000 \\
\hline \multicolumn{5}{|c|}{ B. Biaya Tidak Tetap } \\
\hline 1 & $\begin{array}{l}\text { Biaya listrik } \\
\text { operasional } \\
\text { winch }\end{array}$ & 12 & 125.438 & 1.505 .250 \\
\hline 2 & Penyelam & 12 & 1.000 .000 & 12.000 .000 \\
\hline 3 & $\begin{array}{l}\text { Asisten } \\
\text { operator cradle }\end{array}$ & 12 & 450.000 & 5.400 .000 \\
\hline \multicolumn{3}{|c|}{ Jumlah } & & 172.505 .250 \\
\hline
\end{tabular}

Tabel 13. Pengeluaran docking/ undocking sistem cradle ditahun 2019.

\begin{tabular}{|c|l|c|c|c|}
\hline No & \multicolumn{1}{|c|}{ Parameter } & $\begin{array}{c}\text { Jumlah } \\
\text { Kapal }\end{array}$ & $\begin{array}{c}\text { Biaya/ } \\
\text { Satuan (Rp) }\end{array}$ & $\begin{array}{c}\text { Biaya Per } \\
\text { Tahun } \\
(\mathbf{R p})\end{array}$ \\
\hline \multicolumn{5}{|l|}{ A. Biaya Tetap } \\
\hline 1 & Dok master & & 4.000 .000 & 48.000 .000 \\
\hline 2 & Operator winch & & 3.000 .000 & 36.000 .000 \\
\hline 3 & $\begin{array}{l}\text { Asisten } \\
\text { operator winch }\end{array}$ & 2.800 .000 & 33.600 .000 \\
\hline 4 & $\begin{array}{l}\text { Upah operator } \\
\text { cradle }\end{array}$ & 3.000 .000 & 36.000 .000 \\
\hline B. Biaya Tidak Tetap \\
\hline 1 & $\begin{array}{l}\text { Biaya listrik } \\
\text { operasional } \\
\text { winch }\end{array}$ & 9 & 125.438 & 1.128 .938 \\
\hline 2 & Penyelam & 9 & 1.000 .000 & 9.000 .000 \\
\hline 3 & $\begin{array}{l}\text { Asisten } \\
\text { operator cradle }\end{array}$ & 9 & 450.000 & 4.050 .000 \\
\hline \multicolumn{4}{|l|}{ Jumlah } & 167.778 .938 \\
\hline
\end{tabular}

\subsection{Perhitungan}

Docking/Undocking dan Harian Untuk Sistem Cradle 2017 - 2019

Tabel 14. Pendapatan docking/undocking dan docking dengan sistem cradle pada periode tahun 2017-2019

\begin{tabular}{|c|l|c|}
\hline Tahun & \multicolumn{1}{|c|}{ Parameter } & Jumlah (Rp) \\
\hline \multirow{2}{*}{2017} & Dockin/undocking kapal & 320.000 .000 \\
\cline { 2 - 3 } & Docking harian & 600.000 .000 \\
\hline \multirow{2}{*}{2018} & Dockin/undocking kapal & 240.000 .000 \\
\cline { 2 - 3 } & Docking harian & 260.000 .000 \\
\hline \multirow{2}{*}{2019} & Dockin/undocking kapal & 180.000 .000 \\
\cline { 2 - 3 } & Docking harian & 128.750 .000 \\
\hline \multirow{2}{*}{} & Jumlah & 1.728 .750 .000 \\
\hline
\end{tabular}

\subsection{Perhitungan Laba Rugi Untuk Operasional Docking Kapal Dengan Sistem Cradle Pada Tahun 2017-2019}

Tabel 15. Perhitungan Laba Rugi Sistem Cradle Tahun 2017-2019

\begin{tabular}{|l|l|l|}
\hline \multicolumn{2}{|c|}{ Perhitungan Laba Rugi } \\
\hline \multicolumn{2}{|c|}{ Sistem Cradle 2017 - 2019 } \\
\hline Pendapatan & \multicolumn{1}{l|}{$\begin{array}{l}\text { Rp. } \\
\text { kocking/Undocking } \\
\text { kapal }\end{array}$} & $\begin{array}{l}\text { Rp. } \\
988.750 .000000,00\end{array}$ \\
\hline Docking harian & & $\begin{array}{l}\text { Rp. } \\
1.728 .750 .000,00\end{array}$ \\
\hline Jumlah Pendapatan & & \\
\hline & & \\
\hline Beban usaha & & \\
\hline Dok master & Rp. 144.000.000,00 & \\
\hline Operator winch & Rp. 108.000.000,00 & \\
\hline Ass operator winch & Rp. 100.800.000,00 & \\
\hline Operator cradle & Rp. 108.000.000,00 & \\
\hline Ass operator cradle & Rp. 16.650.000,00 & \\
\hline Penyelam & Rp. 37.000.000,00 & \\
\hline Winch cradle & Rp. $4.641 .187,50$ & \\
\hline Jumlah beban usaha & & Rp \\
& & \\
\hline Laba Bersih & & \\
\hline
\end{tabular}

Laba bersih rata-rata selama tiga tahun

$\mathrm{N}_{\mathrm{L}}=\mathrm{N}_{\mathrm{P}}-\mathrm{N}_{\mathrm{B}}$

$\mathrm{N}_{\mathrm{L}}=$ Rp. $576,250,000.00-$ Rp. $576,250,000.00$

$=$ Rp. 403,219,604.17

\subsection{Selisih Ekonomis Dari Sistem Airbag dan Sistem Cradle Selama Tiga Tahun Terakhir (Periode 2017-2019).}

Berikut ini adalah selisih ekonomis pengeluaran sistem airbag dan sistem cradle (Mahamid, 2011).

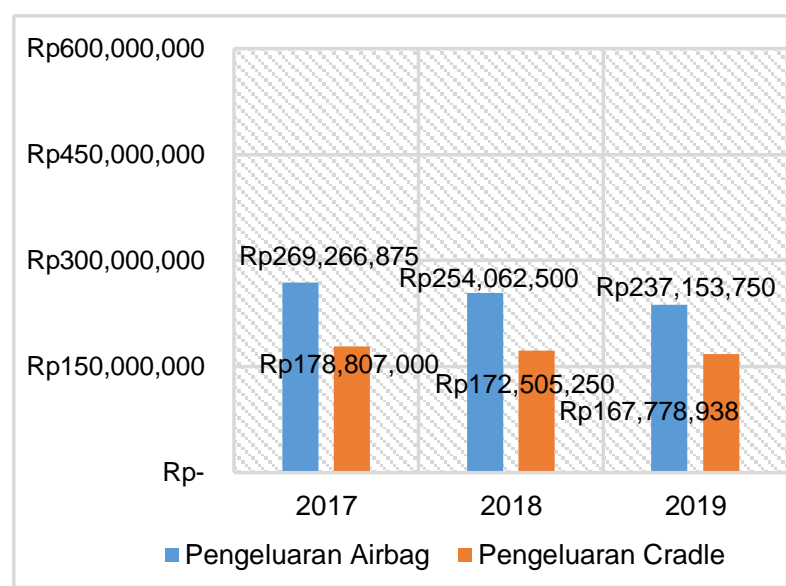

Gambar 2. Perbandingan pengeluaran sistem airbag dan sistem cradle pada tahun 2017-2019 


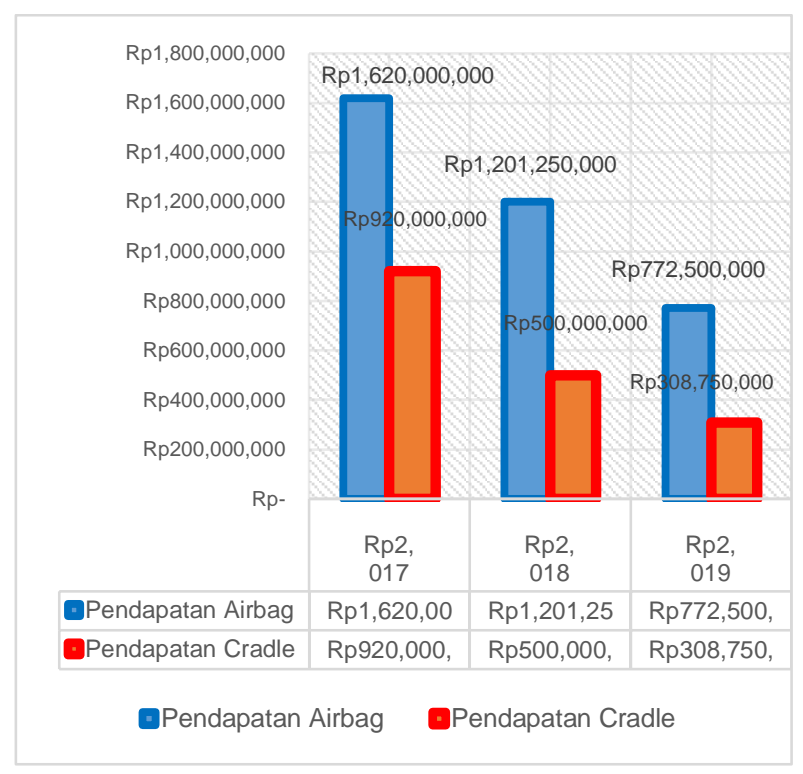

Gambar 3. Perbandigan pendapatan sistem airbag dan sistem cradle pada tahun 2017-2019

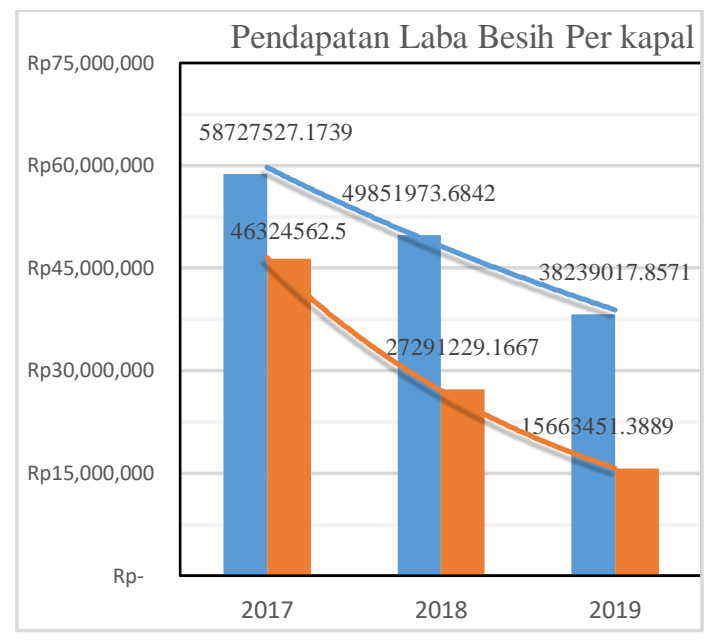

Gambar 4. Pendapatan laba bersih sistem airbag dan sistem cradle pada tahun 2017-2019

Berdasarkan hasil perhitungan maka dapat dilihat besar laba bersih yang dihasilkan oleh satu kapal dengan menggunakan sistem airbag dan sistem cradle semakin jelas.

Dari hasil perhitungan biaya pengeluaran untuk sistem airbag dari tahun 2017-2019 sebesar Rp 760.483.125 dan sistem cradle sebesar Rp. $519,091,188$, sedangkan pendapatan yang didapat dari sistem airbag sebesar Rp. 3,593,750,000 dan sistem cradle sebesar Rp. 1.728.750.000. Dari hasil di atas pendapatan terbanyak adalah pendapatan sistem airbag di tahun 2019 yaitu $79 \%$. Hal ini disebabkan karena lama waktu pengedokan pada sistem airbag lebih banyak walaupun jumlah kapal hanya 14.

\subsection{Pembahasan}

Dari hasil perhitungan laba rugi diperoleh bahwa dengan sistem airbag keuntungan laba bersih yang didapat per satu tahun dari pendapatan docking/undocking kapal, docking harian, pada tahun 2017 adalah sebesar Rp. 1.350.733.125,-. Perhitungan laba rugi pada tahun 2018 keuntungan laba bersih yang didapat sebesar Rp. 947.187.500,dan pada tahun 2019 keuntungan laba bersih yang didapat sebesar Rp. 535.346.250,- sedangkan keuntungan yang didapat sistem airbag per tiga tahun dalam periode tahun 2017-2019 adalah sebesar Rp. 2.833.266.875,-

Hasil perhitungan laba rugi dengan sistem cradle keuntungan yang didapat per satu tahun dari : pendapatan docking/undocking kapal, docking harian, pada tahun 2017 laba bersih yang didapat adalah sebesar Rp. 741.193.000. Perhitungan laba rugi tahun 2018 dengan sistem cradle keuntungan laba bersih yang didapat adalah sebesar Rp. 327.494.750,- dan perhitungan laba rugi pada tahun 2019 laba bersih yang didapat sistem cradle sebesar Rp. 140.971.062,50, sedangkan keuntungan laba bersih yang didapat per tiga tahun dalam periode tahun 2017-2019 adalah sebesar Rp. 1.209.658.812,50. Dari hasil perhitungan, tampak jelas bahwa untuk operasional pengedokan kapal di PT. Dok dan Perkapalan Waiame Ambon lebih menguntungkan dengan menggunakan sistem airbag dimana keuntungan dari sistem airbag per tiga tahun sebesar Rp. 2.833.266.875,- sehingga keuntungan yang didapat dari perusahaan dengan sistem airbag adalah sebesar Rp. 1.623.608.062,50. Penggunaan sistem airbag di Dok Waiame lebih menguntungkan.

\section{KESIMPULAN}

Dari hasil perhitungan biaya operasional dan pendapatan dari docking kapal untuk docking/undocking dan lama waktu di atas dock diperoleh hasil sebagai berikut: keuntungan yang didapat dari docking kapal dengan sistem airbag sebesar Rp. 2.833.266.875,- dan keuntungan yang didapat sistem cradle sebesar Rp. 1.209.658.812,50.

Terlihat jelas bahwa untuk operasional pengedokan kapal di PT. Dok dan Perkapalan Waiame Ambon lebih menguntungkan dengan menggunakan sistem airbag

\section{DAFTAR PUSTAKA}

1. Engstrom, J. E. dan I.O. Engvall, (2010) Method For Selection Of An Optimum Fishing Vessel For Infestment Purpose, FAO, Rome Italy., H.E.Rossels, Principle Of Naval Architecture, Sname 
2. Crispe, Jonathan (2005). Dry Docking and Repair: Bernhard Schulte Ship management (IOM) Ltd

3. Cornick, Henry F,. (1958). Dock and Harbour Engineering. London: Charles Griffin and Company Limited.

4. Leong, The analysis and design of a Sistem cradle system Forrepair And maintenance of boat or small ships. UniversityTechnology Malaysia. 1991,

5. Karogal, Madhav (2015) Vessel Maintenance and Dry Docking; Technical Super intendend Ishima Pte Ltd.

6. Lamb, T. (2004) Ship Design and Construction Volume II. Jersey City: The Society of Naval Architects and Marine Engineers.

7. R. F. D. Mackie, Issue in Dry Docking Economics, Ship lifts, Sistem cradle and Keel Blocks.Consulting Coastal \& Habour Engineer Cape Town, S.Africa. 2006

8. Fitriana, nur dian (2014). Buku praktis menyusun laporan laba rugi. Laskar aksara

9. Gading Sitepu. Hamza dan La Ode Abdul Rahma Firu (2012). Kajian JURNAL TEKNIK ITS Vol. 6, No. 1, (2017) ISSN_ (Print) G-22

10. Heger, Robert (2005). Dock Master Training Manual: Heger Dry Dock,Inc

11. Mahamid, I. Early Cost Estimating for Roads Construction Projects Using Multiple Regression Technique. Hail University, Saudi Arabia. 2011

12. B. Mallick, (1998), Variable Selection for Regression Models. The Indian Journal of Statistics, Series B PP 65-81. 